\title{
A miRNA-PEPTIDE FUSION AS A VACCINE CANDIDATE AGAINST THE NOVEL CORONAVIRUS (COVID-19)
}

Journal of Diabetes and Endocrinology Research

Research Article

*CRUZ-RODRIGUEZ L. ${ }^{*}, 2,3^{*}$, LAMBERT BROWN D. ${ }^{4}$, HOCHWIMMER B. ${ }^{5}$, SELINUS O. ${ }^{6}$, CRUZRODRIGUEZ LD. ${ }^{7}$, CRUZ-RODRIGUEZ ME. ${ }^{7}$, ZAYAS TAMAYO AM. ${ }^{8}$ and SANCHEZ BATISTA L. ${ }^{8}$

${ }^{1 *}$ CEO, ELIDAN genome SAS, 1 avenue du Lycée, 77130

Montereau Fault Yonne; France.

${ }^{2}$ CEO, ELIDAN Dynamic LLC, 1602 Windermere Way, Tampa, FL,33619, USA.

${ }^{3}$ ExCELab Co. Ltd., Manager Director of Environmental

Biotechnology Department., Jamaica.

${ }^{4} C E O$, Family Physician, FCMC \& ExCELab Co. Ltd, Jamaica.

${ }^{5}$ CEO, Hochwimmer B. \& Asso. Pty Ltd, Albury, NSW, Australia.

"Correspondence author

Dr. CRUZ-RODRIGUEZ Luis

CEO,

ELIDAN genome SAS,

1 av du Lycée,

77130 Montereau FY;

France

Submitted : 26 March 2020 ; Published : 10 April 2020

${ }^{7}$ ELIDAN genome SAS, 1 avenue du Lycée, 77130 Montereau

Fault Yonne; France.

${ }^{8}$ ExCELab Co. Ltd., Environmental Biotechnology Department, Jamaica.

\begin{abstract}
A new coronavirus named COVID-19 was reported in Wuhan, China in December 2019. The COVID-19 epidemic is spreading rapidly all over the world, (Sun P. and col, 2020). Based on published data on COVID-19, we have designed a preventive vaccine in Silico aimed to protect against COVID-19 infection and transmission (Cascella M. and col, 2020). One aim of this is to better understand potential dormant repositories of outbreaks and potential spread of those repositories, together with potential geogenic terrain factors (Wang Z., 2019). Here, we present to the miRNA-peptide fusion more stable as antiviral (Waterhouse A. and col 2018). As RNA target we used primers from Kemp V. "miRNA repertoire and host immune factor regulation upon avian coronavirus infection in eggs": primers Biolegio, Nijmegen, The Netherlands (Kemp V. and col, 2019). Our analysis identified a miRNA-peptide with theorical fusion value stability FS=64.28, to treat COVID-19, named LCR_2020_B008-1. Additionally, peptide LCR_2020_B008 can be used in solutions as disinfectant and antiviral, having a fast-hygienic utility to avoid contagion or the propagation of the Covid-19 disease. With respect to antiviral action, the candidate manifests LCR_2020_B008-1, in Silico, manifesting partial inhibiting activity on the VIH-1, and therefore readjustments on this chimera miRNA-peptide could reach a representative antiviral activity against the VIH-1.
\end{abstract}

Keywords: Coronavirus (COVID-19), Chimera miRNA-peptide, theorical Fusion value Stability (FS), Preventive Vaccine in Silico, PARP-1, antiviral LCR_2020_B008-1, peptide LCR_2020_B008

Introduction

According to the World Health Organization (WHO), viral diseases continue to emerge episodically and represent a serious issue to public health. In the last twenty years, several viral epidemics such as the severe acute respiratory syndrome coronavirus (SARS-CoV from 2002 to 2003, and H1N1 influenza in 2009, have been recorded). In December 2019, a cluster of patients with pneumonia of unknown cause was linked to a seafood wholesale market in Wuhan, China. A previously unknown betacoronavirus was identified through the use of unbiased sequencing in samples from patients with pneumonia (Zhu N. and col, 2019).

January 10, 2020, the first 2019-ncov genome was sequenced, followed by five subsequent viral genome sequences (Wang $Z$., 2019). The new coronavirus, formed a clade within the subgenus Orthocoronavirinae, sarbecovirus subfamily. The first time these cases were published they were classified as "pneumonia of unknown etiology." The Chinese Center for Disease Control and Prevention (CDC) and local CDCs organized an intensive outbreak investigation program. The etiology of this illness is 
now attributed to a novel virus belonging to the coronavirus (CoV) family, COVID-19. Different from both MERS-CoV and SARS-CoV, 2019-nCoV it is the seventh member of the family of coronaviruses to infect humans (Cascella P. and col, 2020).

The clinical range of the disease, new diagnostics, prevention and treatment strategies are in process of development. Unfortunately, insufficient research leading up to purported species-species viral transmission is alarming. We know they are more frequently episodic, yet always assume a systemic closed biology. This may be a faulty discipline assumption since the increasing episodic nature of viral transmission bears scrutiny on potential physiographic-climactic links. These in turn are open to geogenic-geological connections with terrain biology and ecology. The whole biological cycle of the virus de and host and the evolution of the epidemic, especially when the epidemic will reach its peak is unknown. Terrain-controlled genomic studies in soil geo-microbiology and invertebrate Medical Geology to higher species-species transmissions studies are recommended. This may extend the viral genomic phylogenic trees beyond the species-species barriers and diversity of potential future impacts. Geologists do not consider the possibility of spreading the disease by air, water, and earth. The discipline of Medical Geology can translate this enigmatic situation using its potential to understand the planet and human health relationships (Centeno JA. and col 2016; Selinus, O. and col 2005; Selinus, O. and col 2010).

One aim of this is to better understand potential dormant repositories of outbreaks and potential spread of those repositories, together with potential geogenic terrain factors and triggers. Integrated research in vaccine testing with such 'wild type' genomic diversity research is recommended to be also open to viral Medical Geology studies, as a new discipline (Hochwimmer B. and Cruz-Rodriguez L., 2005; CruzRodriguez L, 2005).

A better wild-type viral genomics understanding leading up to the current pandemic of COVID-19 is needed along with research into potential dormant repositories of outbreaks and the spread of those repositories, geogenic terrain factors and triggers. This will help understand the episodic, recurring and frequent nature of outbreaks and potential virulent and contagious future outbreaks. Here we have identified a miRNA-peptide fusion:

3'AAAAAAAAAA----

CTCCTAGAACTAGCATTACAGATG----

CCCCCVNCDTFCAGSTFISDEVDGVDEVAKKKSK

Peptide with fusion value stability $\mathrm{FS}=64.28$, as the vaccine candidate that we propose to integrate in the research in vaccine testing with 'wild type' genomic phylogenic evolution studies as a part of viral Medical Geology studies utilizing a small part of the viral vaccine funding recommended.

\section{Materials and Methods}

Homology modelling has evolved into an important procedure in structural biology, significantly contributing to narrowing the gap between known protein sequences from a virus and designed protein in Silico structures.

Antiviral proteins were designed to be used as protein inhibitors. The inhibition is due to protein on protein interactions. A cleavage site has been adjusted (DEVD) in the peptide to induce the caspases 3 and 7 action, and thereby apoptosis in infected cells.

On the other hand, in cells not infected apoptosis is not induced, and the synthesis of the miRNA will allow an antigen involved in production of antibodies against the COVID-19 and also HIV-1 to appear.

The miRNA 3' and peptide N-terminus will both be modified for click chemistry conjugation.

\section{Gene targets:}

Ontology enrichment analysis

The primers used as miRNA targets were:

(Biolegio, Nijmegen, The Netherlands)

\section{- NFAT3C_FW1(CTCCTAGAACTAGCATTACAGATG) \\ - NFAT3C_RV1(GACCAGGTGATGGAGTTGGAG) \\ - NFAT5 FW1(CACTGAGGTGCCACGTAAATC) \\ - $\quad$ NFAT5 RV1(GCTTTTGAGTTGCCTTTGCTG) \\ - SPPL3_FW2(GTAGCAGACTATTACCTACGTG) \\ - $\quad$ SPPL3_RV2(GAAGCTTCAGTTTGCCTAACTG) \\ - TGFB2_FW1(GCAAGATTTGCAGGTATTGATGAC) \\ - TGFB2 RV1(CCTGCACATTCCTAAAACAA) \\ - JUN_FW1(GCAGAGCATGACGCTGAACCTG) \\ - JUN_RV1(CTTGCTCGTCGGTAACGTTC) \\ - IBV5'GU391_fw(GCTTTTGAGCCTAGCGTT) \\ - IBV5'GL533_rv(GCCATGTTGTCACTGTCTATTG) \\ - housekeepinggeneGAPDH FW92(GAAGGCTGGGGCTCATCTG) \\ - GAPDH_RV92(CAGTTGGTGGTGCACGATG) \\ - housekeepinggeneACTB FW89(CAACACAGTGCTGTCTGGTGGTA) \\ - ACTB_RV89 (ATCGTACTCCTGCTTGCTGATCC)}

All primers were validated for their stability after peptide fusion. Statistical analysis (Waterhouse A. and col, 2018). 


\begin{tabular}{|c|c|c|c|c|c|c|c|}
\hline DNA & A & $\mathrm{T}$ & $\mathrm{C}$ & G & SUMA & PRIMER & PEPTIDE \\
\hline $\mathrm{a}$ & 18 & 6 & 6 & 4 & 34 & $\begin{array}{l}\text { AAAAAAAAAA-- } \\
\text { CTCCTAGAACTAG CATTACAGATG }\end{array}$ & $\begin{array}{l}\text { CCCCC-- } \\
\text { VNCDTFCAGSTFISDEVDGVDEVAKKKSK }\end{array}$ \\
\hline $\mathrm{b}$ & 13 & 4 & 2 & 10 & 29 & $\begin{array}{l}\text { AAAAAAAA-- } \\
\text { GACCAGGTGATG GAGTTGGAG }\end{array}$ & $\begin{array}{l}\text { CCCCC-- } \\
\text { VNCDTFCAGSTFISDEVDGVDEVAKKKSK }\end{array}$ \\
\hline $\mathrm{c}$ & 14 & 4 & 6 & 5 & 29 & $\begin{array}{l}\text { AAAAAAAA-- } \\
\text { CACTGAGGTGCCA CGTAAATC }\end{array}$ & $\begin{array}{l}\text { CCCCC-- } \\
\text { VNCDTFCAGSTFISDEVDGVDEVAKKKSK }\end{array}$ \\
\hline $\mathrm{d}$ & 9 & 10 & 4 & 6 & 29 & $\begin{array}{l}\text { AAAAAAAA-- } \\
\text { GCTTTTGAGTTGCCTTTGCTG }\end{array}$ & $\begin{array}{l}\text { CCCCC-- } \\
\text { VNCDTFCAGSTFISDEVDGVDEVAKKKSK }\end{array}$ \\
\hline $\mathrm{e}$ & 14 & 6 & 5 & 5 & 30 & $\begin{array}{l}\text { AAAAAAAA-- } \\
\text { GTAGCAGACTA TTACCTACGTG }\end{array}$ & $\begin{array}{l}\text { CCCCC-- } \\
\text { VNCDTFCAGSTFISDEVDGVDEVAKKKSK }\end{array}$ \\
\hline$f$ & 13 & 7 & 5 & 5 & 30 & $\begin{array}{l}\text { AAAAAAAA-- } \\
\text { GAAGCTTCAGTTTG CCTAACTG }\end{array}$ & $\begin{array}{l}\text { CCCCC-- } \\
\text { VNCDTFCAGSTFISDEVDGVDEVAKKKSK }\end{array}$ \\
\hline $\mathrm{g}$ & 15 & 7 & 3 & 7 & 32 & $\begin{array}{l}\text { AAAAAAAA-- } \\
\text { GCAAGATTTGCAGGT ATTGATGAC }\end{array}$ & $\begin{array}{l}\text { CCCCC-- } \\
\text { VNCDTFCAGSTFISDEVDGVDE VAKKKSK }\end{array}$ \\
\hline $\mathrm{h}$ & 16 & 4 & 7 & 1 & 28 & $\begin{array}{l}\text { AAAAAAAA-- } \\
\text { CCTGCACATTCCTAAAACAA }\end{array}$ & $\begin{array}{l}\text { CCCCC-- } \\
\text { VNCDTFCAGSTFISDEVDGVDE VAKKKSK }\end{array}$ \\
\hline $\mathrm{i}$ & 14 & 3 & 6 & 7 & 30 & $\begin{array}{l}\text { AAAAAAAA-- } \\
\text { GCAGAGCATGACG CTGAACCTG }\end{array}$ & $\begin{array}{l}\text { CCCCC-- } \\
\text { VNCDTFCAGSTFISDEVDGVDEV AKKKSK }\end{array}$ \\
\hline j & 10 & 7 & 6 & 5 & 28 & $\begin{array}{l}\text { AAAAAAAA-- } \\
\text { CTTGCTCGTCG GTAACGTTC }\end{array}$ & $\begin{array}{l}\text { CCCCC-- } \\
\text { VNCDTFCAGSTFISDEVDGVDEVA KKKSK }\end{array}$ \\
\hline $\mathrm{k}$ & 10 & 7 & 4 & 5 & 26 & $\begin{array}{l}\text { AAAAAAAA-- } \\
\text { GCTTTTGAGCCTAGCGTT }\end{array}$ & $\begin{array}{l}\text { CCCCC-- } \\
\text { VNCDTFCAGSTFISDEVDGVDEVA KKKSK }\end{array}$ \\
\hline 1 & 11 & 9 & 5 & 5 & 30 & $\begin{array}{l}\text { AAAAAAAA-- } \\
\text { GCCATGTTGTCACTG TCTATTG }\end{array}$ & $\begin{array}{l}\text { CCCCC-- } \\
\text { VNCDTFCAGSTFISDEVDGVDEVA KKKSK }\end{array}$ \\
\hline $\mathrm{m}$ & 11 & 4 & 4 & 8 & 27 & $\begin{array}{l}\text { AAAAAAAA-- } \\
\text { GAAGGCTGGGGC TCATCTG }\end{array}$ & $\begin{array}{l}\text { CCCCC-- } \\
\text { VNCDTFCAGSTFISDEVDGVDEVA KKKSK }\end{array}$ \\
\hline $\mathrm{n}$ & 11 & 5 & 3 & 8 & 27 & $\begin{array}{l}\text { AAAAAAAA-- } \\
\text { CAGTTGGTGGTGCA CGATG }\end{array}$ & $\begin{array}{l}\text { CCCCC-- } \\
\text { VNCDTFCAGSTFISDEVDGVDEVA KKKSK }\end{array}$ \\
\hline o & 13 & 6 & 5 & 7 & 31 & $\begin{array}{l}\text { AAAAAAAA-- } \\
\text { CAACACAGTGCTGTCT GGTGGTA }\end{array}$ & $\begin{array}{l}\text { CCCCC-- } \\
\text { VNCDTFCAGSTFISDEVDGVDEVA KKKSK }\end{array}$ \\
\hline $\mathrm{p}$ & 11 & 8 & 8 & 4 & 31 & $\begin{array}{l}\text { AAAAAAAA-- } \\
\text { ATCGTACTCCTGCTT GCTGATCC }\end{array}$ & $\begin{array}{l}\text { CCCCC-- } \\
\text { VNCDTFCAGSTFISDEVDGVDEVA KKKSK }\end{array}$ \\
\hline
\end{tabular}

Table 1: shows the 16 DNA primers used as fusion with the selected peptide for the vaccine against the human Coronavirus. On the table the number of nitrogenated bases and the size of the primer can be seen. The Polyadenylation (number of Adenines adjusted at the $5^{`}$ end of the primer and the number of Cys adjusted to the peptided utilized as a spacing arm between the RNA and the peptide.)

This peptide begins with the aminoacid Cysteine (C) to facilitate fusion with the 5' of miRNA.

The peptide utilized was the following:

- $\quad$ Full peptide sequencing (34 aminoacids)

CCCCCVNCDTFCAGSTFISDEVDGVDEVAKKKSK

https://blast.ncbi.nlm.nih.gov/Blast.cgi\#alnHdr_

YP 009725299

NON-STRUCTURAL POLYPROTEIN 1AB [BAT SARS-

LIKE CORONAVIRUS]

2. HUMAN PARP-1 (11 aminoacids) GVDEVAKKKSK

After cleavage of caspase $3 / 7$

1. SARS-CoV-2 (23 aminoacids)

CCCCCVNCDTFCAGSTFISDEVD

https://blast.ncbi.nlm.nih.gov/Blast.cgi\#alnHdr_QHW06038

ORF1ABPOLYPROTEIN [SEVEREACUTERESPIRATORY SYNDROME CORONAVIRUS 2]

https://blast.ncbi.nlm.nih.gov/Blast.cgi\#alnHdr_AAL02174 poly (ADP-ribose) polymerase, partial [Homo sapiens]

The mathematical formula utilized to estimate the stability of the fusion between miRNA and the selected peptide was:

FS=abcd, where:

$a=\frac{S_{\text {Poly } A}}{S_{\text {Poly Cys }}}, \quad b=\frac{M W_{\text {miRNA }}}{M W_{\text {Peptide }}}, c=\frac{S_{\text {Peptide }}}{S_{\text {miRNA }}}$, $d=\frac{[2(A+B)+3(C+G)]}{X\left(p I_{1}, p I_{2}, \ldots, p I_{n}\right)}$, 
$S_{\text {PolyA }}$ : Poly A size

$S_{\text {Poly Cys }}$ : Poly Cys size

$M W_{\text {miRNA }}$ : miRNA Molecular Weight

$M W_{\text {Peptide }}$ : Peptide Molecular Weight

$S_{\text {Peptide }}$ : Pepetide size [aa]

$S_{\text {miRNA }}$ : miRNA Size

$\mathrm{B}=\mathrm{T}$ if DNA or $\boldsymbol{B}=\boldsymbol{U}$ if RNA

pI: point Isoelectric

n: peptide size

Formula developed by Dr. Luis CRUZ-RODRIGUEZ and named as Fusion Stability CRUZ-RODRIGUEZ (FS).

\section{Results and Discussion}

Bioinformatics identification of miRNAs

Prior to analysis, readings containing poly-N, with 5' Cyspeptide fusion with a 3' insert tag, containing poly-A (add 8 nucleotides of Alanine to all primers except primer to which 10 nucleotides of Alanine were added). The small miRNA was clustered with a peptide with caspase site, and the percentage of differential of Fusion Stability (FS) RNA-peptide was calculated. The mapped small RNA reads were examined for the presence of known miRNAs using MiRBase20.0

(http://www.mirba se.org/). Based on this analysis 16 vaccine candidates were identified (Table 2 below). The Differential miRNA-peptide fusion stability curve was calculated (fig. 1).

a. $\mathrm{NFAT3C}$

FW1(3'CTCCTAGAACTAGCATTACAGATG5'),

3'AAAAAAAAAA

CTCCTAGAACTAGCATTACAGATG

CCCCCVNCDTFCAGSTFISDEVDGVDEVAKKKSK

$\mathrm{FS}=\mathbf{6 4}, 28$

b. NFAT3C

RV1(3'GACCAGGTGATGGAGTTGGAG5'),

3'AAAAAAAA

GACCAGGTGATGGAGTTGGAG

CCCCCVNCDTFCAGSTFISDEVDGVDEVAKKKSK

$\mathrm{FS}=\mathbf{5 8 , 9 3}$

c. NFAT5_FW1(3'CACTGAGGTGCCACGTAAATC5'),

3'AAAAAAAA

CACTGAGGTGCCACGTAAATC

CCCCCVNCDTFCAGSTFISDEVDGVDEVAKKKSK

$\mathbf{F S}=\mathbf{5 6 , 9 7}$

d. NFAT5 RV1(3'GCTTTTGAGTTGCCTTTGCTG5'),

3'AAAAAAAA

GCTTTTGAGTTGCCTTTGCTG

CCCCCVNCDTFCAGSTFISDEVDGVDEVAKKKSK

$\mathrm{FS}=\mathbf{5 6 , 2 1}$ e. SPPL3_FW2(3'GTAGCAGACTATTACCTACGTG5'),

3'AAAAAAAA

GTAGCAGACTATTACCTACGTG--

CCCCCVNCDTFCAGSTFISDEVDGVDEVAKKKSK

$\mathbf{F S}=\mathbf{5 7 , 8 5}$

f. SPPL3 RV2(3'GAAGCTTCAGTTTGCCTAACTG5'), 3'AAAAAAAA

GTAGCAGACTATTACCTACGTG

CCCCCVNCDTFCAGSTFISDEVDGVDEVAKKKSK

$\mathbf{F S}=\mathbf{5 7 , 7 9}$

g. TGFB2

FW1(3'-GCAAGATTTGCAGGTATTGATGAC5'),

3'AAAAAAAA

GCAAGATTTGCAGGTATTGATGAC--

CCCCCVNCDTFCAGSTFISDEVDGVDEVAKKKSK

$\mathrm{FS}=\mathbf{6 1 , 6 2}$

h. TGFB2_RV1(3'CCTGCACATTCCTAAAACAA5'),

3'AAAAAAAA

CCTGCACATTCCTAAAACAA

CCCCCVNCDTFCAGSTFISDEVDGVDEVAKKKSK

$\mathbf{F S}=\mathbf{5 2 , 2 9}$

i. JUN_FW1(3'GCAGAGCATGACGCTGAACCTG5'),

3'AAAAAAAA

GCAGAGCATGACGCTGAACCTG

CCCCCVNCDTFCAGSTFISDEVDGVDEVAKKKSK

$\mathbf{F S}=\mathbf{6 0 , 5 5}$

j. JUN_RV1(3'CTTGCTCGTCGGTAACGTTC5'),

3'AAAAAAAA

CTTGCTCGTCGGTAACGTTC CCCCCVNCDTFCAGSTFISDEVDGVDEVAKKKSK

$\mathbf{F S}=\mathbf{5 5 , 1 3}$

k. IBV5'GU391_FW(3'GCTTTTGAGCCTAGCGTT5'),

3'AAAAAAAA

GCTTTTGAGCCTAGCGTT

CCCCCVNCDTFCAGSTFISDEVDGVDEVAKKKSK

$\mathbf{F S}=\mathbf{5 0 , 4 4}$

1. IBV5'GL533

RV(3'GCCATGTTGTCACTGTCTATTG5'),

3'AAAAAAAA

GCCATGTTGTCACTGTCTATTG CCCCCVNCDTFCAGSTFISDEVDGVDEVAKKKSK

$\mathbf{F S}=\mathbf{5 7 , 6 8}$

m. GAPDH_FW92(3'GAAGGCTGGGGCTCATCTG5'),

3'AAAAAAAA

GAAGGCTGGGGCTCATCTG

CCCCCVNCDTFCAGSTFISDEVDGVDEVAKKKSK

$\mathbf{F S}=\mathbf{5 5 , 0 9}$

n. GAPDH_RV92(3'CAGTTGGTGGTGCACGATG5'),

3'AAAAAAAA

CAGTTGGTGGTGCACGATG

CCCCCVNCDTFCAGSTFISDEVDGVDEVAKKKSK

$\mathrm{FS}=\mathbf{5 4 , 3 4}$

o. $\mathrm{ACTB}$

FW89(3'CAACACAGTGCTGTCTGGTGGTA5'),

3'AAAAAAAA

CAACACAGTGCTGTCTGGTGGTA

CCCCCVNCDTFCAGSTFISDEVDGVDEVAKKKSK

$\mathrm{FS}=61,37$ 
p. ACTB RV89(3'ATCGTACTCCTGCTTGCTGATCC5'). 3'AAÄAAAAA

ATCGTACTCCTGCTTGCTGATCC CCCCCVNCDTFCAGSTFISDEVDGVDEVAKKKSK $\mathrm{FS}=\mathbf{6 0 , 5 0}$

(a, $b, c, d, e, f, g, h, I, j, k, l, m, n . o, p:$ are sixteen DNA-peptide fusion candidates. The DNA primer is translated to RNA for the proposed vaccine against the Covid19.

Figure 1 below shows the stability value of the fusion among different DNA: $a, b, c, d, e, f, g, h, I, j, k, l, m, n . o, p)$.

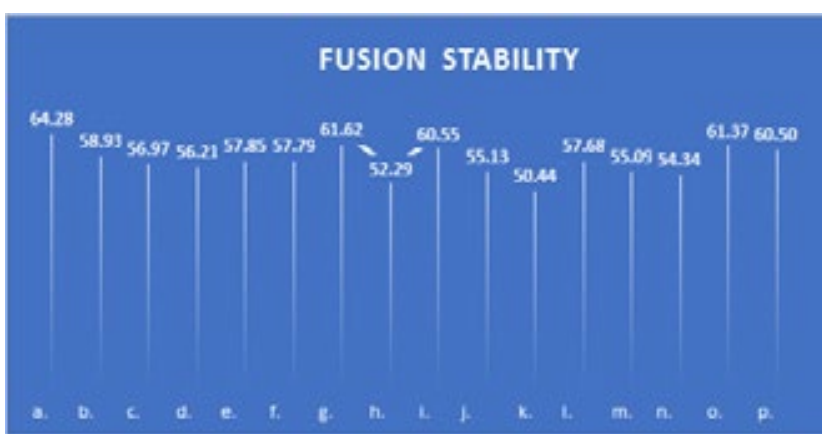

The selected peptide is:

3'AAAAAAAAAA---

CTCCTAGAACTAGCATTACAGATG---

CCCCCVNCDTFCAGSTFISDEVDGVDEVAKKKSK

The fusion stability most representative was 64.28 and was named: ANTIVIRAL CHEMICAL CHIMERA FORMULA LCR 2020 B008-1: Antiviral chemical chimera formula: against Human Coronavirus (Covid19).

DNA:'3'AAAAAAAAAA----

CTCCTAGAACTAGCATTACAGATG---CCCCCVNCDTFCAGSTFISDEVDGVDEVAKKKSK

Candidate selected: miRNA:

5'AAAAAAAAAA---

CUCCUAGAACUAGCAUUACAGAUGCCCCCVNCDTFCAGSTFISDEVDGVDEVAKKKSK $\mathrm{FS}=\mathbf{6 4 . 2 8}$

Using ProMod3 and the introduction a new local model quality estimation method, QMEANDisCo. SWISS-MODEL (https://swissmodel.expasy.org). (Waterhouse A., 2018), here, we present an update to the SWISS-MODEL server, with several candidates of antiviral Covid19/VIH1 vaccine miRNA-peptide.

https://swissmodel.expasy.org/interactive/88DDHj/models/

From candidate selected: miRNA poly-A (34 nt)-peptide (23

a)

5'AААААААААА---

CUCCUAGAACUAGCAUUACAGAUGCCCCCVNCDTFCAGSTFISDEVDGVDEVAKKKSK
We present an update to: miRNA, full peptide sequencing and the two peptides after caspase 3/7 cleavage.

- $\quad$ miRNA poly-A (34 nt)-peptide (23 aa) + peptide (11 aa) 5'AAAAAAAAAA---

CUCCUAGAACUAGCAUUACAGAUG-

CCCCCVNCDTFCAGSTFISDEVDGVDEVAKKKSK

https://blast.ncbi.nlm.nih.gov/Blast.cgi\#1797068551

Leptospira interrogans serovar Copenhageni strain SK1 chromosome I

- $\quad$ miRNA (24 nt)

5'CUCCUAGAACUAGCAUUACAGAUG https://blast.ncbi.nlm.nih.gov/Blast.cgi\#1390069545

Phasianus colchicus nuclear factor of activated $\mathrm{T}$ cells 3 (NFATC3), transcript variant X1, miRNA

\section{Conclusions and Perspectives}

Our analysis in Silico identified a stable fusion miRNApeptide from 16 vaccine candidates aimed to treat COVID-19 infections.

The vaccine candidate with the highest FS was named: LCR_2020_B008-1: Patent Rights: 2003293481905.

It presents a cleavage site for enzymes Caspase- 3 and caspase-7 are both activated universally during apoptosis, irrespective of the specific death-initiating stimulus, and both proteases are widely considered to coordinate the demolition phase of apoptosis by cleaving as a protein substrate. Inoculation is expected to be orally with appropriate doses.

Additionally, the peptide

VNCDTFCAGSTFISDEVDGVDEVAKKKSK can be used in solutions as viral disinfectant, which can have a fast-hygienic utility to avoid contagion and the propagation of the Covid-19 disease.

With regards to the antiviral action, the candidate manifests LCR_2020_B008-1, in Silico, manifests a partial inhibiting activity on the VIH-1, which means that readjustments in this chimera miRNA-peptide could reach a representative antiviral activity against the VIH-1. 
Acknowledgments

Thanks to:

- Ms. Marie Elisabeth CRUZ-RODRIGUEZ

- Mr. Luis Daniel CRUZ-RODRIGUEZ

- Ms. Estrella Marina RODRIGUEZ VALLADARES

- Prof. Dr. Patrick VERNET

- Mr. Oslay CRUZ RODRIGUEZ

- Mr. Eduardo Jesús MARRERO RODRIGUEZ

- Mr. Raúl RODRIGUEZ VALLADARES

- Ms. Teresita DIAZ ALVAREZ

- Mr. Eduardo MARRERO MESA

- Dr. Omar MARRERO MESA

- Dr. David LAMBERT BROWN

- Ms. Connie CRUZ

- Ms. Yadira SAU BARROSO

- Ms. Raquel ALMAGUER VERDECIE

- Dr. Eriel MARTINEZ

- Dr. Chaosheng ZHANG

- Mr. Francisco RODRIGUEZ

- Mr. José Luis CAPARROS CAPARROS

- Mr. Camilo RODRIGUEZ VALLADARES (specially)

\section{References}

1. Cascella M, Rajnik M, Cuomo A, Dulebohn SC, Di Napoli R (2020) "Features, Evaluation and Treatment Coronavirus (COVID-19)", SourceStatPearls. Treasure Island (FL): StatPearls Publishing; 2020-Mar 8.

2. Centeno JA, Finkelman RB. and Selinus O (2016) "Medical Geology: Impacts of the Natural. Environment on Public Health": Geosciences 6: 8; doi:10.3390/ geosciences 6010008

3. Cruz-Rodriguez L, Hochwimmer B., Selinus O (2005); Medical Geology in Cuba. 2005, ISBN 9697117037.

4. Hochwimmer B and Cruz-Rodriguez L (2005) "The Polygonal Vortex Mineralisation Model: a predictive tool of health indices and the proposed use of such "geologically based public health indices as a sub discipline of Medical Geology”. 2005, ISBN 9697117037.

5. Kemp V, Laconi A, Cocciolo G, Berends AJ, Breit T, Verheije MH (2020) "miRNA repertoire and host immune factor regulation upon avian coronavirus infection in eggs", Archives of Virology https://doi.org/10.1007/ s00705-020-04527-4

6. Selinus, O, Finkelman, B, Centeno, JA (2009) Editors. Medical Geology - a regional synthesis. Springer. 2010.

7. Selinus O, Alloway B, Centeno JA, Finkelman RB, Fuge R, Lindh U, Smedley P (Editors) (2005) Essentials of Medical Geology. Elsevier, Amsterdam, 820 p. (second edition published by Springer 2012).

8. Sun P, Lu X, Xu C, Sun W, Pan B (2020) "Understanding of COVID-19 based on current evidence", J Med Virol. 2020 Feb 25. doi: 10.1002/jmv.25722.

9. Wang Z (2020) “A Handbook of 2019-nCoV Pneumonia Control and Prevention", Hubei Science and Technology
Press. January 2020

10. Waterhouse A, Bertoni M, Bienert S, Studer G, Tauriello G, Gumienny R, Heer FT, de Beer TAP, Rempfer C, Bordoli L, Lepore R, Schwede T (2018) "SWISSMODEL: homology modelling of protein structures and complexes", Nucleic Acids Res. 2018 Jul 2: 46(W1): W296-W303. doi: 10.1093/nar/gky427.

11. Zhu N, Zhang D, Wang W, Li X, Yang B, Song J, Zhao X, Huang B, Shi W, Lu R, Niu P, Zhan F, Ma X, Wang D, Xu W, Wu G, Gao GF, Tan W (2020) "A Novel Coronavirus from Patients with Pneumonia in China, 2019." N Engl J Med. 382(8): 727-733. doi: 10.1056/NEJMoa2001017.
Copyright: C2020 CRUZ-RODRIGUEZ Luis. This is an open-access article distributed under the terms of the Creative Commons Attribution License, which permits unrestricted use, distribution, and reproduction in any medium, provided the original author and source are credited. 